\title{
Epizootiological study of rickettsiosis of the Saint- Jacques scallop Pecten maximus
}

\author{
G. Le Gall, E. Mialhe, D. Chagot, H. Grizel \\ Laboratoire de Pathologie et de Génétique des Invertébrés Marins, IFREMER, B.P. 133, F-17390 La Tremblade, France
}

\begin{abstract}
Rickettsia-like microorganisms were described in gill endothelial cells during mass mortalities of Saint-Jacques scallops Pecten maximus in Saint-Brieuc Bay (North Brittany, France) during winter 1985-86. In order to evaluate the epizootiological significance of rickettsiosis of scallops, an analytical and descriptive epizootiological study was undertaken. The study included the geographic distribution, incidence and severity of the disease for several northern European and French scallop populations. Since the center of French scallop production is in Saint-Brieuc Bay, epizootiological investigations were concentrated in this area. Dissemination appeared to be by horizontal transmission. The pathogenic significance of the rickettsia-like organism in mortalities of $P$. maximus is discussed.
\end{abstract}

\section{INTRODUCTION}

Towards the end of February 1986, mass mortalities were reported in beds of Pecten maximus at SaintBrieuc (North Brittany, France), which is the center of French scallop production. Similar mortalities reoccurred during the same periods of the 2 following years. The scallop production loss was estimated at ca 10000 tons for the 3 years and total scallop mortalities ranged from 20 to $30 \%$ (Dao pers. comm.).

Initial histopathologic investigation of the mortalities was undertaken during March 1987. Rickettsia-like infection within the gill endothelial cells was described but no evidence of a deleterious effect on affected tissues was found (Le Gall et al. 1988a).

Rickettsia-like and Chlamydia-like infections have been reported in several marine bivalve molluscan species (Lauckner 1983), noticeably among Pectinidae: Placopecten magellanicus (Gulka et al. 1983); Argopecten irradians (Morrison \& Shum 1982, 1983, Leibovitz et al. 1984, Leibovitz 1986); Patinopecten yessoensis (Elston 1986a). Rickettsia-like microorganisms were occasionally associated with mass mortalities of cultivated adult bivalves (Comps \& Raimbaud 1978, Gulka et al. 1983, Elston 1986b). In hatchery-reared larval and post-metamorphic $A$. irradians, chlamydiosis was established as an extremely lethal epizootic disease, although enzootic for adults (Leibovitz 1989). While a limited understanding of the morphology of these procaryotic pathogens exists, their actual signifi- cance and specificity as agents of molluscan diseases is poorly understood. To gain a better understanding of the pathogenic role of Pecten maximus rickettsiae, the following descriptive and analytic epizootiological study was undertaken.

\section{MATERIAL AND METHODS}

Scallops. Young ( 1 to $2 \mathrm{yr}$ ) and adult ( 3 to $5 \mathrm{yr}$ age) Pecten maximus were collected between 1985 and 1989 from several French and northern European beds (Fig. 1). The size and frequency of samplings varied with geographic area. In Saint-Brieuc Bay, where the epizootiological survey was more extensive, all of the scallops collected were dredged from an experimental bed free of commercial fishing.

Juvenile scallops were obtained either directly from the Argenton hatchery (IFREMER, Brittany) or at different ages from the English Channel (scallops ranged in size from 6 to $30 \mathrm{~mm}$ ) and from the Mediterranean Sea ( $40 \mathrm{~mm}$ in size).

Two hatches of larvae, produced by methods described by Buestel et al. (1982) from infected Saint-Brieuc brood stock, were employed for rickettsial transmission studies. One hatch received chloramphenicol $\left(8 \mathrm{mg} \mathrm{l}^{-1}\right)$ during the first $28 \mathrm{~d}$ of larval rearing; the second hatch did not receive chloramphenicol and served as an experimental control to evaluate the effect of the antibiotic on rickettsial development (Ormsbee et al. 1955). 


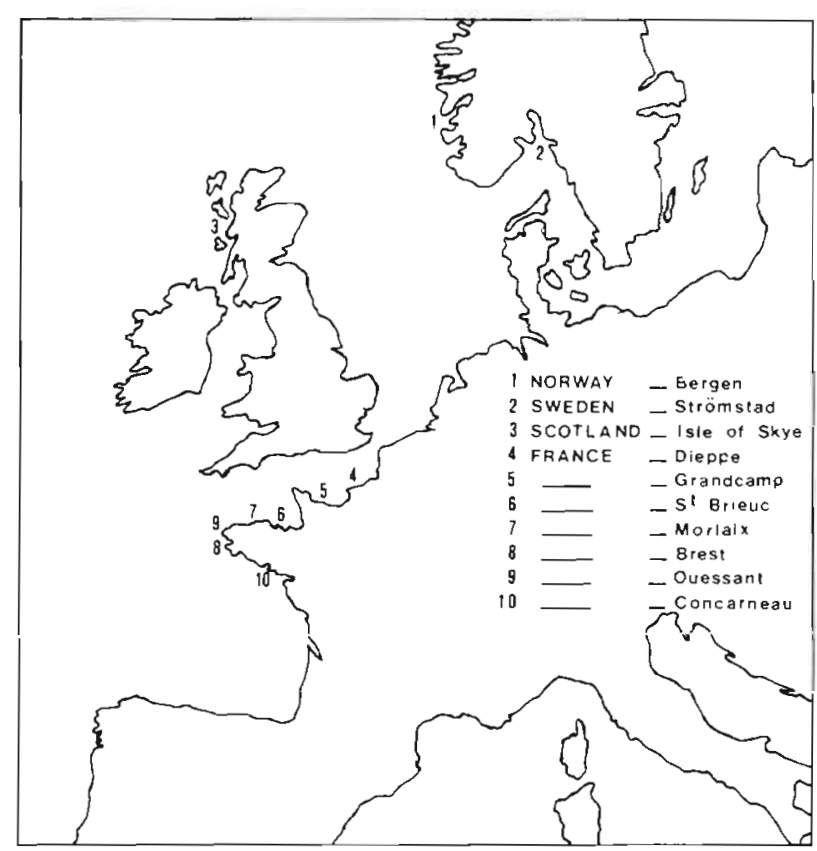

Fig. 1. Location of Pecten maximus samples collected for the epidemiological study

Histology. Light microscopy: Rickettsial infections were routinely detected by light microscopic examination of paraffin sections $(3 \mu \mathrm{m})$ prepared from Carson fixed gills and stained by hematoxylin-eosin. For adult scallops, the prevalence $\left(P_{i}\right.$ no. of individuals infected/ no. examined) and degree of individual infection $\left(d_{i}\right.$ no. of colonies on 4 slides) were estimated by counting the rickettsial colonies observed in 4 transverse gill sections taken at different levels of the organ. For juvenile scallops, these estimations were made from a single longitudinal histologic section through the 2 gills of a single juvenile.

Indirect immunofluorescence (IIF): In some cases, the indirect immunofluorescence test was employed for rickettsial examinations of larval or post-metamorphic scallop tissue smears. The specific immune serum for this test was produced in mice immunized against purified rickettsiae of Pecten maximus. The specific antibodies against scallop antigens were eliminated through acetonic extraction of gills of healthy scallops (Mialhe et al. 1988).

Experimental infections. Four month old scallops (10 to $15 \mathrm{~mm}$ ) were experimentally infected by immersion (bath method). For this purpose, suspensions of ca $3 \times 10^{8}$ partially purified rickettsiae were introduced in 3 doses, each delivered at 3 dintervals into 101 seawater tanks containing 50 scallops. These scallops, which were obtained directly from the hatchery, had never been in contact with infected adults and were assumed to be rickettsia-free. Histologic examinations were negative for ricketisiae. Experimentally infected and uninfected control scallops were maintained separately under similar feeding and water quality conditions.

Statistical analysis. Significance testing of differences observed for degrees of infection, origin and sampling date of experimental groups of scallops were made by a 1 -way variance analysis (ANOVA, Statgraphics) after data transformation of the non-parametric 1-way analysis by rank (Krustal-Wallis, Statgraphics). When the use of the parametric ANOVA was possible, a multiple range analysis was subsequently used to determine homogeneous groups.

\section{RESULTS}

\section{Geographic distribution, prevalence and infection degree of Pecten maximus rickettsiosis}

Prevalences $(P)$ and degrees of infection $(d)$ of Pecten maximus rickettsiosis were estimated for several northern European scallop populations (Table 1). Scallops from all locations were aged between 3 and 5 yr.

Scallops from Norway, the most northern area studied, appeared rickettsia-free based upon histologi-

Table 1. Pecten maximus. Rickettsial prevalence $(P)$ and mean degree of infection (d) with standard deviation (SD) in European populations examined in winter 1987/88 and in winter 1988/89. N: number of samples

\begin{tabular}{|c|c|c|c|c|c|c|c|c|c|}
\hline \multirow{2}{*}{\multicolumn{2}{|c|}{ Origin of samples }} & \multicolumn{4}{|c|}{$1987 / 1988$} & \multicolumn{4}{|c|}{$1988 / 1989$} \\
\hline & & Date & $N$ & $p$ & $d(\mathrm{SD})$ & Date & $N$ & P & $d(\mathrm{SD})$ \\
\hline Norway: & Bergen & 22 Aug 88 & 20 & 0 & $-\quad-$ & - & - & - & - \\
\hline Sweden: & Strömstad & 23 Feb 88 & 7 & $2 / 7$ & $2.5(0.5)$ & - & - & - & - \\
\hline Scotland: & Skye & $21 \mathrm{Jan} 88$ & 27 & $3.7 \%$ & $1.0 \quad(-)$ & - & - & - & - \\
\hline \multirow[t]{7}{*}{ France: } & Dieppe & $21 \mathrm{Jan} 88$ & 22 & $100 \%$ & $37.8\{23.5\}$ & - & - & - & - \\
\hline & Grandcamp & $23 \operatorname{Dec} 87$ & 30 & $100 \%$ & $24.5(19.8)$ & - & - & - & - \\
\hline & St. Brieuc & 14 Oct 87 & 20 & $100 \%$ & $51.2(38.4)$ & 11 Nov 88 & 32 & $100 \%$ & $129.5(88.8$ \\
\hline & Morlaix & $01 \operatorname{Dec} 87$ & 30 & $100 \%$ & $-\quad-$ & - & - & - & - \\
\hline & Brest & 01 Dec 87 & 30 & $90 \%$ & $3.5(2.3)$ & 11 Nov 88 & 20 & $100 \%$ & $16.5(8.0)$ \\
\hline & Ouessant & 16 Dec 87 & 54 & $26 \%$ & $1.2(0.5)$ & - & - & - & - \\
\hline & Concarneau & $16 \operatorname{Dec} 87$ & 30 & $67 \%$ & $3.7(3.5)$ & 26 Oct 88 & 50 & $96 \%$ & $19.5(17.1)$ \\
\hline
\end{tabular}


cal examination of 20 scallops collected in August 1988. At a more southern location in Scandinavia, near Strömstad in Sweden, 2 of 7 samples were slightly infected $(d=2.5)$. In Scotland (Isle of Skye), only one rickettsia colony was found in one scallop out of 27 .

A more extensive epizootiological survey was undertaken in France as a result of close contacts with fishermen and scientists interested in the fall in scallop production. All of the French scallop populations were found to be infected. Prevalences during the winters of 1987-88 ranged between $26 \%$ at Ouessant Island and $100 \%$ for scallop populations along the English Channel. Mean values for the degree of infection $(d)$ were estimated at $51.2( \pm 38.4)$ for Saint-Brieuc, and 37.8 ( \pm 23.6) and 24.5 ( \pm 19.8) for Dieppe and Grandcamp, respectively. In these 3 areas with maximal prevalences $(P=100 \%)$, the degrees of infection were higher than those established for scallops from Brest ( $P$ $=90 \% ; d=3.5 \pm 2.3)$, Concarneau $(P=67 \% ; d=3.7$ $\pm 3.5)$ and Ouessant $(P=26 \% ; d=1.2 \pm 0.5)$. A 1-way analysis of variance (ANOVA) applied to the degrees of infection of the different French areas indicated the influence of the geographic origin of scallop sampled. A multiple range analysis led to the recognition of 3 homogeneous groups according to their level of infection. The first group, of highest infection, was identified as scallops from Saint-Brieuc, Dieppe and Grandcamp. The second group consisted of scallops from Brest and Concarneau and the third, with the lowest infection, was those from Ouessant.

During winter 1988-89, the epizootiological survey made at Saint-Brieuc Bay, where the prevalence was always $100 \%$, revealed a significant increase in the degree of infection from $d=51.2( \pm 38.4)$ in 1987 to $d=$ 129.5 ( \pm 88.8 ). At Brest and Concarneau, an increase of prevalences was observed, from 90 to $100 \%$, and significantly from 67 to $96 \%$, respectively. Degrees of infection stayed relatively low $(d=16.5 \pm 8.0$ and $d=19.5 \pm 17.1)$, but were also significantly increased compared to the preceding year, being ca 5 times higher.

\section{Epizootiological survey in Saint-Brieuc Bay}

An extensive epizootiological survey of the disease in Saint-Brieuc Bay was undertaken because of its prime importance in French scallop production. Histological studies were conducted on fixed specimens collected in September 1985, prior to the first reported mortalities. Numerous samples were collected regularly between March 1987 and April 1989. No rickettsial colonies were detected in histological sections prepared from scallops collected during September 1985. Regardless of time of collection during the year, maximal prevalence was observed in all samples collected after March 1987. However, large fluctuations in degrees of infection were noted (Table 2). Results suggested that mortalities observed at the end of the winter of 1987-88 followed an increase in degrees of infections between October and December and coincided with the disap-

Table 2. Pecten maximus. Rickettsial prevalence $(P)$ and mean degree of infection $(d)$ in Saint-Brieuc Bay with standard deviation (SD) time course according to sampling date. N: number of samples

\begin{tabular}{|lccc|}
\hline Sampling date & $N$ & $P$ & $d \pm$ SD \\
\hline 18 Sep 85 & 10 & $0 \%$ & 0 \\
12 Mar 87 & 21 & $100 \%$ & - \\
14 Oct 87 & 20 & $100 \%$ & $51.2 \pm 38.4$ \\
17 Dec 87 & 30 & $100 \%$ & $111.9 \pm 72.6$ \\
28 Apr 88 & 18 & $100 \%$ & $95.5 \pm 81.5$ \\
04 Jun 88 & 29 & $100 \%$ & $51.9 \pm 30.6$ \\
11 Nov 88 & 32 & $100 \%$ & $129.5 \pm 88.8$ \\
23 Dec 88 & 64 & $100 \%$ & $249.5 \pm 153.0$ \\
24 Apr 89 & 49 & $100 \%$ & $229.5 \pm 167.6$ \\
\hline
\end{tabular}

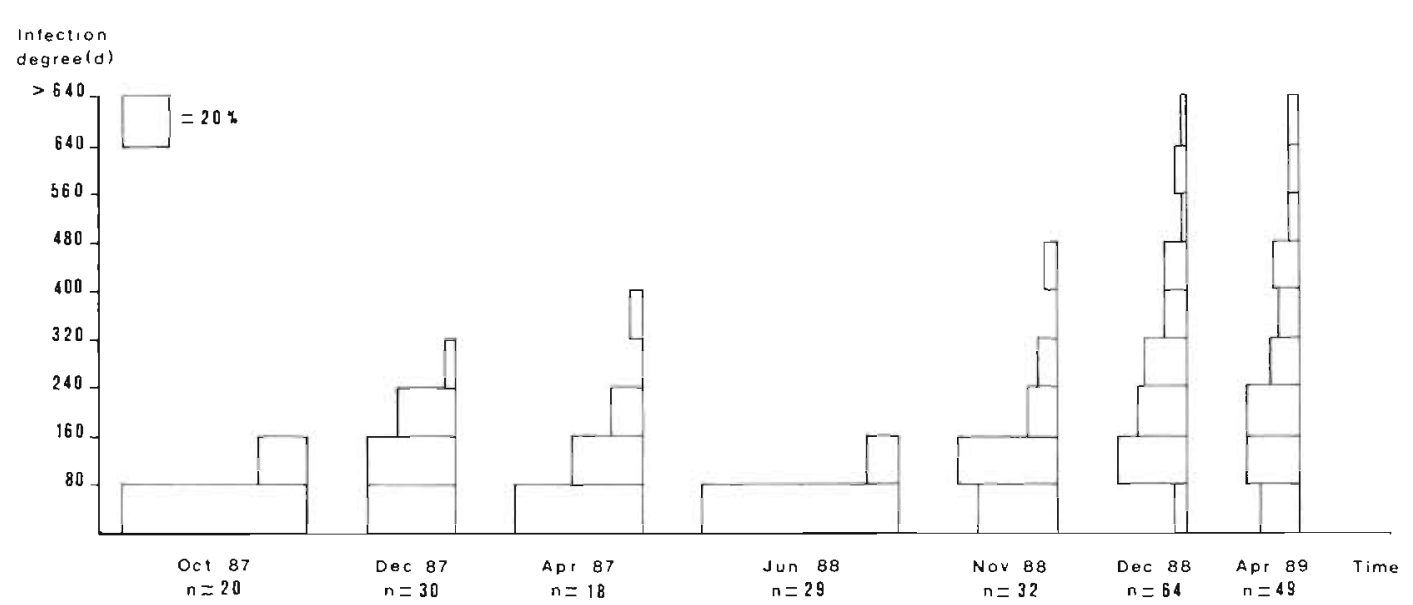

Fig. 2. Pecten maximus. Time course of frequency of infection degree $(d)$ in Saint-Brieuc scallops between October 1987 and April 1989. For each sample, the total surface corresponds to $100 \%$; n: number of samples 
pearance of heavily infected scallops during spring 1988 (Fig. 2). This relationship between time and infection was statistically confirmed, leading to the conclusion that scallops were significantly more heavily infected during this winter period.

In 1988-89, the epizootiological survey was repeated by analyzing larger samples in November, December and April (Table 2). Evidence was obtained of an intensification of rickettsiosis; the degrees of infection significantly increased from the beginning of winter reaching mean values equal to $d=249.5 \pm 153$ in December and $d=229.5 \pm 167.6$ in April. As shown in the frequency histograms (Fig. 2), about $30 \%$ of the scallops had higher degrees of infection compared to maximal values found the preceding year $(d=111.9 \pm 72.6)$ in December.

The corratation between the degree of infection and the age of the scallops was studied separately for adults and juveniles, since rickettsiae were quantified using

Table 3. Pecten maximus. Mean degree of infection (d) with standard deviation (SD) established for juveniles by counting colonies on a longitudinal section through the 2 gills, and for adults by counting colonies on 4 transverse gill sections. All scallops were collected from Saint-Brieuc Bay. N: number of samples

\begin{tabular}{|lccrrr|}
\hline $\begin{array}{l}\text { Sampling } \\
\text { date }\end{array}$ & $\begin{array}{c}\text { Rearing } \\
\text { time }\end{array}$ & $\begin{array}{c}\text { Size } \\
\text { (height in mm) }\end{array}$ & $N$ & $d \pm$ SD \\
\hline Mar 88 & $1 \mathrm{mo}$ & $06-10$ & 30 & 0 & \\
Mar 88 & $4 \mathrm{mo}$ & $14-22$ & 50 & $8.0 \pm$ & 6.0 \\
Mar 88 & $10 \mathrm{mo}$ & $28-32$ & 15 & $49.9 \pm 48.6$ \\
$\operatorname{Dec} 87$ & $18 \mathrm{mo}$ & $80-90$ & 15 & $126.1 \pm 76.5$ \\
$\operatorname{Jan} 89$ & $3 \mathrm{yr}$ & $100-110$ & 13 & $191.8 \pm 75.5$ \\
$\operatorname{Jan} 89$ & $4 \mathrm{yr}$ & $100-110$ & 11 & $136.8 \pm 125.7$ \\
$\operatorname{Jan} 89$ & $5 \mathrm{yr}$ & $110-120$ & 10 & $186.9 \pm 68.2$ \\
\hline
\end{tabular}

different methods for each age group. In spite of the low number of samples, no apparent difference in the degree of infection was found relative to the age of adult scallops (Table 3). Hatchery-produced juveniles, examined at various intervals within 1 mo after being placed in lobster pots in the bay, were found to be rickettsia-free, whereas juveniles which were maintained for 4 mo and longer in the open sea had maximal prevalences $(P=100 \%)$

The degree of infection, estimated from longitudinal sections of the 2 gills, increased from a mean of $d=8.0$ ( \pm 6.0 ) for juveniles 14 to $22 \mathrm{~mm}$ to $d=49.9$ ( \pm 48.6) for those measuring $30 \mathrm{~mm}$ and exposed for $10 \mathrm{mo}$ in the bed (Table 3).

\section{Mode of rickettsial transmission}

\section{Vertical transmission hypothesis}

The possibility of vertical transovarian transmission was tested by looking for rickettsiae in larvae of infected breeding scallops from Saint-Brieuc, using indirect immunofluorescence (IIF). Two hatches, one treated with chloramphenicol and the other untreated, were analyzed. Histological examinations of both hatches, examined at 2,8 , and $20 \mathrm{~d}$ of age, were negative. The results were also negative at 27 and $35 \mathrm{~d}$ of age for the hatch treated with antibiotic; however, the untreated hatch was very difficult to interpret due to bacterial contamination resulting in nonspecific background fluorescence. Histological examinations of the gills of 50 other juveniles, produced by the same infected broodstock in the same hatchery and grown in the Mediterranean Sea, were negative for rickettsiae (Comps pers. comm.).

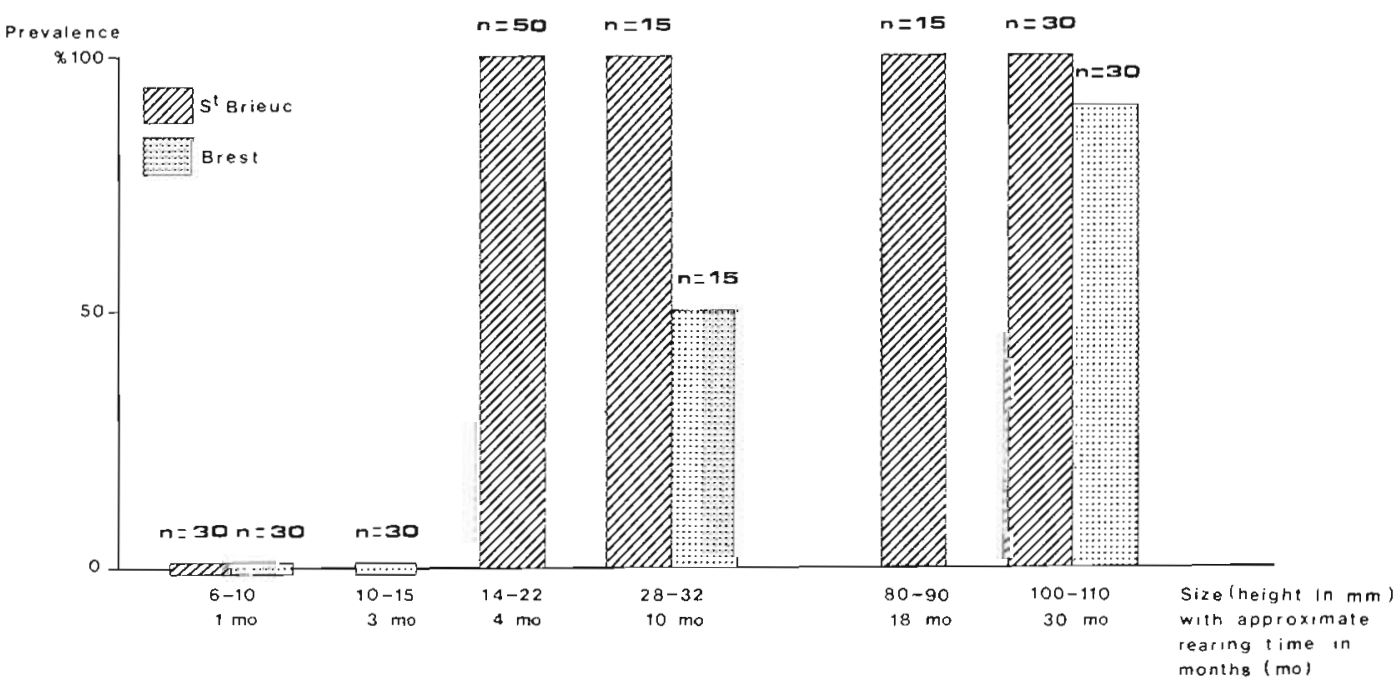

Fig. 3. Pecten maximus. Rickettsial infection prevalence according to age of juveniles originating from hatchery (Argenton, North Brittany] and reared for different periods in Saint-Brieuc Bay or in Brest Bay. The histological study was performed during winter 1987/1988. n: number of samples 


\section{Horizontal transmission hypothesis}

Employing IIF, fluorescent procaryotes were detected in smears from 3 juveniles out of 15 observed $1.5 \mathrm{mo}$ after experimental (bath) immersion with rickettsiae. Fluorescence was not detected in similar experimental scallops treated without antibody. Smears of control scallops reacted with rickettsia-specific antibodies were also negative. Three months later, rickettsiae were found in 7 sacrificed experimentally exposed scallops, one of which had a pronounced infection. All of the unexposed sacrificed control scallops were rickettsiafree at the termination of the experiment. The horizontal transmission hypothesis was also considered by analyzing the prevalence and degree of infection in juveniles from the grow-out system of the same hatchery (Fig. 3). In Saint-Brieuc Bay, infection was detected in all juveniles which were reared for 4 mo in the open sea ( $d=8.0$ \pm 6.0 ). After 10 mo rearing in the open sea, the degrees of infection were greatly increased $(d=49.9 \pm 48.6)$. In Brest Bay, rickettsiae were not associated with juveniles less than $15 \mathrm{~mm}$ in size, and only $50 \%$ of 10 mo cultured young scallops were positive with lower degrees of infection $(d=1.75 \pm 0.97)$.

\section{Alternate host hypothesis}

Samples of gills, gonad and digestive gland of Crepidula fornicata, removed from infected scallop shells, were found negative for rickettsiae. Rickettsial colonies were found in the branchial filaments of 2 related pectinid species, Chlamys varia and $C$. opercularis. However, based upon morphologic, biochemical, and serological analyses, these rickettsiae were distinctive from those associated with Pecten maximus (Le Gall et al. 1988b, Le Gall et al. unpubl.).

\section{DISCUSSION}

Histological analysis of Pecten maximus samples collected in Saint-Brieuc Bay after the onset of mortalities led to the identification of a gill rickettsia infection (Le Gall et al. 1988a). The absence of this rickettsial infection in scallops collected in the same area before the first mortalities led to the hypothesis that the rickettsia was the etiologic agent of an infectious disease. In spite of some other cases of rickettsiosis associated with bivalve mortalities, the lack of epizootiological data limits the understanding of the actual impact of these microorganisms on the host populations. The present study was intended to assess the prevalence, degrees of infection, the influence of the age of the host and the geographic distribution of the disease.
Prevalences of the disease varied widely within Europe. Norway was an apparent scallop rickettsia-free zone. Thus it may be assumed that the association of rickettsia with Pecten maximus is not obligatory and should not be interpreted as a symbiotic relationship. Intracellular symbiotic procaryotes have been described in several arthropod species (Weiss et al. 1986) and abyssal bivalves (Le Pennec et al. 1988). A more detailed epizootiological survey revealed highly infected French populations, especially along the English Channel where prevalences were greatest. Such strong differences between the prevalences in French and northern European regions prompt speculation as to the origin and extension of rickettsiosis of scallops. It is possible that the disease started in unspecified areas of SaintBrieuc Bay and had spread towards other European beds. In contrast, the marked epizootic nature of rickettsiosis in France might have resulted from the introduction of infected scallops into a rickettsia-free area. In fact, some spat have been imported since 1982, during a Saint-Brieuc restocking program, from Scotland and Ireland. It should be noted that, at that time, Irish spat was found to be infected with rickettsia (Tige pers. comm.). However, it is difficult to support a single hypothesis since rickettsiosis was found in areas where no introductions were known, and furthermore no specimens were taken for analysis prior to 1987.

Production decreases have been observed since 1986 in the areas of highest prevalences and degrees of infection: Saint-Brieuc, Grandcamp and Dieppe. Moreover, a significant exacerbation of rickettsiosis, based upon observations of prevalence and degrees of infection, occurred during the winter of 1988-1989 for the populations of Saint-Brieuc, Brest and Concarneau.

In spite of the limitations of histological quantification methods, it is noteworthy that rickettsiosis was exacerbated in winter and was followed by the disappearance of the scallops with the greatest degrees of infection in spring. The temporal coincidence of disappearance of highly infected individuals with increase in mortalities further supported greater rickettsial pathogenicity during this time. Taken together, the data tend to incriminate rickettsiosis in the scallop mortalities. Nevertheless, the seasonality of the disease, as demonstrated by the data, suggests a possible interaction with physiological and/or environmental factors. This would be consistent with other classic examples of disease pathogenesis. Long-term epizootiological surveys and physiological research will be required for the investigation of the pathogenesis of Pecten maximus rickettsiosis. Experiments are in progress in the laboratory simulating a variety of environmental factors that may be correlated with the severity of rickettsial infection and scallop metabolism. 
The infection process was investigated by analyzing the development of the infection with the age of the scallop. Severe infections could be observed in adult scallops of all ages. Juveniles quickly become infected when placed in an area of rickettsiosis; however, the prevalence and degree of infection was found to be related to the local disease level. These observations demonstrate the prime importance of the environment in the transmission of rickettsiae. Three possible methods of transmission of procaryotes have been proposed (Weiss 1981). The first, vertical transovarian transmission, i.e. via the ovary from generation to generation, has been established for several arthropods. For the other 2 modes, transmission is linked to external parameters. Horizontal transmission may be by simple proximity, the infecticus agent being spread in the environment (air and water), or through an alternate host (vector), such as hematophagous or phytophagous invertebrates.

In this study, the vertical transmission hypothesis was rejected since larvae from infected breeders reared without antibiotic were consistently negative for rickettsia. Moreover, juveniles obtained from the same infected broodstock and reared in a rickettsia-free area (Mediterranean Sea) were negative for rickettsiae after several months. On the other hand, it may be assumed that horizontal transmission was an efficient mode of infection since similar juveniles of the same age kept in Saint-Brieuc Bay and those exposed to experimental bath infection became heavily infected. As purified rickettsiae survive in seawater for several hours (data not shown), rickettsiae liberated from gill tissues are probably infective for other scallops.

It was initially believed that related pectinids, such as Chlamys opercularis (Le Gall et al. 1988b) and $C$. varia, constituted alternate hosts for Pecten maximus rickettsia. However, the morphological and serological characteristics of the rickettsia-like organisms in these species are distinct from those associated with $P$. maximus.

At this stage of epizootiological study, it is not possible to define completely the role environmental factors act in synergy with Pecten maximus rickettsiae upon a compromised host. This pathogen can be distinguished from other bivalve parasites like Bonamia ostrea, the hemocytic disease agent of the flat oyster Ostrea edulis (Pichot et al. 1980), whose pathogenicity appears to be a more intrinsic characteristic of the parasite. P. maximus rickettsiosis may be an interesting disease model, suitable for analysing interactions between pathogen, environment and host in the study of disease pathogenesis. It would be especially interesting to test the involvement of the host immune system, particularly as to resistance or susceptibility with varying age. Leibovitz (1989) reported that chlamydiosis was highly virulent for larval bay scallops Argopecten irradians, but relatively avirulent for adults. Such a progressive increase in resistance is also well known against some viruses in other invertebrate groups (Evans 1986). Trials are in progress introducing Mediterranean rickettsia-free juveniles or young scallops into infected areas to evaluate their respective susceptibility.

Finally, the economic importance of pectiniculture, the frequency of rickettsiosis and the probable involvement of the Pecten maximus rickettsiae in the winter mortalities make it essential to extend these epizootiological studies to other scallop species and other countries. Since the histologic methods employed in this study are inadequate for mass sample analyses, more efficient tools for rapid and quantitative diagnostic methods should be developed. For such purposes, immunodiagnostic tools, including monoclonal antibodies and DNA probes, would constitute choice alternative methods.

Acknowledgements. The authors are most grateful to Prof. Emeritus L. Leibovitz of Cornell University, Ithaca, New York, USA for reviewing the manuscript, to $\mathrm{Mr}$ J. C. Dao, IFREMER, Brest, Mr C. Halary and Mr Y. Royer of Comite d'Expansion Economique des Côtes du Nord for collecting live samples, and to Mr J. P. Cochard of IFREMER Brest for larval rearing.

\section{LITERATURE CITED}

Buestel, D., Cochard, J. C., Dao, J. C., Gérard, A. (1982) Production artificielle de naissain de coquilles Saint-Jacques Pecten maximus $\mathrm{L}$. Premiers résultats en rade de Brest. Vie mar. 4: 24-28

Comps, M., Raimbaud, R. (1978). Infection rickettsienne de la glande digestive de Donax trunculus L. Sci. Pèche 281: $11-12$

Elston, R. A. (1986a). Occurence of branchial rickettsiales-like infections in two bivalve molluscs, Tapes japonica and Patinopecten yessoensis, with comments on their significance. J. Fish Dis. 9: 69-71

Elston, R. A. (1986b). An intranuclear pathogen [Nuclear Inclusion X (NIX)] associated with massive mortalities of the Pacific razor clam Siliqua patula. J. Invert. Pathol. 47 93-104

Evans, H. F. (1986). Ecology and epizootiology of baculoviruses. In: Granados, R. A., Federici, B. A. (eds.) The biology of baculoviruses, Vol. II, Chap. 4. CRC Press Inc., Boca Raton, p. 89-132

Gulka, G. Chang, P. W., Marti, K. A. (1983). Procaryotic infection associated with a mass mortality of the sea scallop Placopecten magellanicus. J. Fish. Dis. 6: 355-364

Lauckner, G. (1983). Diseases of Mollusca: Bivalvia. In: Kinne, O. (ed.) Diseases of marine animals, Vol. II, Chap. 13. Biologische Anstalt Helgoland, Hamburg, p. 477-961

Le Gall, G., Chagot, D., Mialhe, E., Grizel, H. (1988a). Branchial rickettsial-like infection associated with a mass mortality of sea scallop Pecten maximus. Dis. aquat. Org. 4: 229-232

Le Gall, G., Chagot, D., Mialhe, E., Grizel, H. (1988b). Mise en évidence d'une infection rickettsienne chez Chlamys opercularis (Pectinidae) et comparaison avec la rickettsie de 
l'espèce sympatrique Pecten maximus. Proc. 3rd Int. Colloq. Pathol. Marine Aquaculture, Gloucester Point, VA, USA, 2-6 Oct. 1988, 15-16

Leibovitz, L. (1986). Chlamydiosis, a newly reported serious disease of larval and postmetamorphic bay scallops Argopecten irradians. Proc. 6th Annual Shellfish Biology Workshop, Milford, Connecticut, 4 March 1986

Leibovitz, L. (1989). Chlamydiosis, a newly reported serious disease of larval and postmetamorphic bay scallops, Argopecten irradians. (Lamarck). J. Fish. Dis. 12: 125-136

Leibovitz, L., Schott, E. F., Karney, R. C. (1984). Diseases of wild, captive and cultured scallops. J. World Maricult. Soc. 15: $169-283$

Le Pennec, M., Diouris, M., Herry, A. (1988), Endocytosis and lysis of bacteria in gill epithelium of Bathymodiolus thermophilus, Thyasira flexuosa and Lucinella divaricata (Bivales, Molluscs). J. Shellfish Res. 7 (3): 483-489

Mialhe, E., Boulo, V., Grizel, H., Rogier, H., Paolucci, F. (1988). Monoclonal antibodies: a tool for molluscan pathology. In: Fisher, W. S. (ed.) Disease processes in marine bivalve molluscs. American Fisheries Society Special Publication 18, Bethesda, Maryland, p. 304-310

Morrison, C., Shum, G. (1982). Chlamydia-like organisms in

Responsible Subject Editor: A. K. Sparks, Seattle, Washington, USA the digestive diverticula of the bay scallop. Argopecten irradians (Lmk). J. Fish. Dis. 5: 173-184

Morrison, C., Shum, C. (1983). Rickettsias in the kidney of the bay scallop, Argopecten irradians (Lmk). J. Fish. Dis. 6: $537-541$

Ormsbee, R. A., Parker, H., Pickens, G. (1955). The comparative effectiveness of aureomycin, terramycin, chloramphenicol, erythromycin and thiomycin in suppressing experimental rickettsial infections in chick embryos. J. infect. Dis. 96: 162-167

Pichot, Y., Comps, M., Tige, G., Grizel, H., Rabouin, M. (1980). Recherche sur Bonamia ostreae gen. n., sp. n., parasite nouveau de l'huitre plate Ostrea edulis L. Revue Trav. Inst, Pêch. marit. 43: 131-140

Weiss, E. (1981). The family Rickettsiaceae: human pathogens. In: Truper, H. G., Balows, A., Schlegel, E. G. (eds.) The procaryotes, a handbook on habitats isolation and identification of bacteria, Vol. II. Springer-Verlag, Berlin, p. $2137-2160$

Weiss, E., Dasch, G., Chang, P. (1986). Genus VII: Wolbachia. In: Buchanan, R. E., Gibbons, N. E. (eds.) Bergey's manual of determinative bacteriology. Williams \& Wilking Co., Baltimore, p. 711-713

Manuscript first received: April 2, 1990

Revised version accepted: January 3,1991 